Int. J. Odontostomat.,

13(1):19-22, 2019.

\title{
Color Stability of Acrylic Resin Teeth After Immersion in Staining Solutions
}

\author{
Análisis del Cambio de Color de Dientes Artificiales \\ Tras Inmersión en Soluciones Colorantes
}

\begin{abstract}
Kalena Melo Maranhão'; Ana Cassia Reis²; Renata Antunes Esteves; Hervé Louis Ghislain; Viviane Garcia4; Eveline Alencar ${ }^{4}$ \& Eliza Burlamaqui Klautau ${ }^{3}$
\end{abstract}

MARANHÃO, K. M.; REIS, A. C.; ESTEVES, R. A.; GHISLAIN, H. L.; GARCIA, V.; ALENCAR, E. \& KLAUTAU, E. B. Color stability of acrylic resin teeth after immersion in staining solutions. Int. J. Odontostomat., 13(1):19-22, 2019.

ABSTRACT: The objective of this study was to evaluate the color alteration of four brands of artificial teeth (Art Plus, Trilux, Bionote and Biolux), after immersion in color solutions of coffee, red wine and urucum. We used 80 artificial teeth, which were standardized with $2 \mathrm{~mm}$ thickness. Then, they were subjected to finishing and polishing, and divided into 4 groups $(n=05)$, which were immersed in one of the 3 types of dye, plus distilled water (control). The samples were immersed daily for 4 hours, then they were removed, washed in tap water, dried with absorbent paper and immersed in distilled water for the subsequent hours in a biological glasshouse at $37^{\circ} \mathrm{C}$, for 21 days. The evaluation of the color change was made in the periods of $0,7,14$ and 21 days, by means of the tristimulus colorimeter. The data were subjected to the ANOVA and Tukey test with a $5 \%$ significance. The results showed that the urucum was the substance that caused the greatest staining while the coffee and the wine did not show statistical difference. Regarding trademarks, Trilux presented a statistical difference compared to the other commercial brands, revealing colorimetric alteration only in the 14-day period. It was concluded that the composition of the artificial teeth, the type of pigmenting agent and the immersion time determine the color change.

KEY WORDS: color change, stock tooth, colorimeter.

\section{INTRODUCTION}

The increase in aesthetic need in dentistry is responsible for the constant and increasing search for knowledge of dental materials, especially dental prosthesis, which requires aesthetic attention in relation to other dental specialties.

The rehabilitation of totally or partially edentulous patients relies on an increasing series of treatment options, varying mainly in the characteristics of the materials of the prostheses. The stock teeth, as well as all restorative material, are susceptible to chromatic alterations when exposed to the buccal environment, where there is commonly the ingestion of certain foods and beverages with coloring substances (Montenegro, 2001; Câmara de Sá, 2001; Miyazaki et al., 2002; Cardoso et al., 2003; Hollis et al., 2015). However, its higher or lower pigmentation is still poorly studied, as well as the influence of the time factor.

The present work has the objective of evaluating the color change of four artificial tooth marks (Art Plus, Trilux, Bionote and Biolux), after immersion in solutions coffee dyes, red wine and urucum.

\section{MATERIAL AND METHOD}

Eighty artificial teeth of the Art Plus, Trilux, Bionote and Biolux brands were used, which were standardized with $2 \mathrm{~mm}$ thickness, by means of the

\footnotetext{
${ }^{1}$ Uninassau's Dental School, Belém, Pará, Brasil.

${ }^{2}$ Famaz's Dental School, Belém, Pará, Brasil.

${ }^{3}$ Ufpa's Dental School, Belém, Pará, Brasil.

${ }^{4}$ Cesupa'S Dental School, Belém, Pará, Brasil.
} 
minicut $(\mathrm{HM} 75 \mathrm{FX})$ palatal surface wear. Then, they were subjected to finishing and surface polishing with Sof-Lex disks (3M) in the four granulations, in descending order in order to plan irregularities left by the drill (Chiappetta \& Reis, 2005).

After preparation, the artificial teeth were divided into 4 groups $(n=05)$ and immersed respectively in $20 \mathrm{ml}$ of the solutions: distilled water (control), coffee (Santa Clara), dry red wine (Trentino) and urucum (Mariza). The specimens were immersed in the respective solutions per daily period of 4 hours for 21 consecutive days and the daily exchange of the dye solutions was performed.

After the dye solutions were removed, the samples were washed in running water for 5 minutes, dried on absorbent paper and placed in containers containing distilled water $(20 \mathrm{ml})$ to be stored in a biological oven at $37^{\circ} \mathrm{C}$ to 20 hours later (Fig. 1).

Subsequently, the specimens were submitted to 4 readings: initial, after 7,14 and 21 days respectively, using a tristimulo colorimeter, which has a detection system, according to the primary colors (red green and blue). The values of the colorimeter were obtained using the system $L{ }^{*} a{ }^{*} b$ * of the International Commission of l'Eclairage (CEI) as the baseline where the value of $L^{*}$ is called clarity (phycosmetric) that oscillates between black color with positive values and the white color with negative values, being that the increase of the positive value shows greater pigmentation leading to the loss of clarity or luminosity, the values of $a^{*}$ and $b{ }^{*}$ are coordinates of the phycosmetric chroma, with $a$ * indicating the red color on the side positive and the green color on the negative side, and the higher the positive value of $a^{*}$, the greater the red color absorption and the more negative values, the lower red color absorption or the greater green color absorption, while the value of $b$ * shows the yellow color on the positive side and the blue color on the negative side (Fig. 2). The total color difference of the samples considering before and after treatments could be calculated by the formula:

$$
\mathrm{DE}=\left[\left(\mathrm{DL}^{*}\right) \sum+\left(\mathrm{Da}{ }^{*}\right) \sum+\left(\mathrm{Db}{ }^{*}\right) \Sigma\right] 12 \text {. }
$$

Then, the data were tabulated and submitted to statistical analysis using the ANOVA and Tukey tests, at a significance level of $5 \%$.

\section{RESULTS AND DISCUSSION}

The results of this work showed that all the stock teeth of the brands Art Plus, Trilux, Bionote and Biolux presented, in general, colorimetric alteration when exposed to the coloring substances, although evidencing a statistically significant difference between them.

It was observed that the annatto was the substance that caused the most chromatic alteration, after 21 days of storage (Fig. 1), whereas coffee and wine did not present statistical difference $(p>0.05)$.

Although the results indicated that there was no significant difference $(p>0.05)$ between the coffee and wine solutions, it was observed that the wine solution caused a greater color change compared to the coffee solution (Fig. 2), according to Câmara de Sa, Türker et al. (2006) and Ertas et al. (2006), while the works of Montenegro report the reverse.

The teeth immersed in urucum presented a significant increase in yellow color and loss of luminosity during the first week of immersion, while red color remained stable, but in the reading between 14 and 21 days a significant increase of the red pigments and yellow, which promoted an orange coloration to the specimens. On the other hand, samples immersed in wine showed a greater red color absorption with loss of brightness and luminosity, while the samples immersed in coffee showed a gradual gain of red pigment.

Urucum is a natural dye used to pigment foods and cosmetics, whose main pigment is carotenoid bixin. It should be emphasized that its influence on the colorimetric alteration of the artificial teeth has not yet been clarified in any research in this area, making it difficult to compare the results. However, unlike urucum, red wine and coffee are widely used substances with proven ability to stain, this occurs not only by the presence of dyes but also by the action of alcohol present in the composition of the wine, because according to Domingues et al. (2001), the alcohol weakens the structure of the resin and facilitates the incorporation of pigments.

Examining the results obtained in Table I, it was observed that, by establishing the periods analyzed, there was a statistical difference in the 


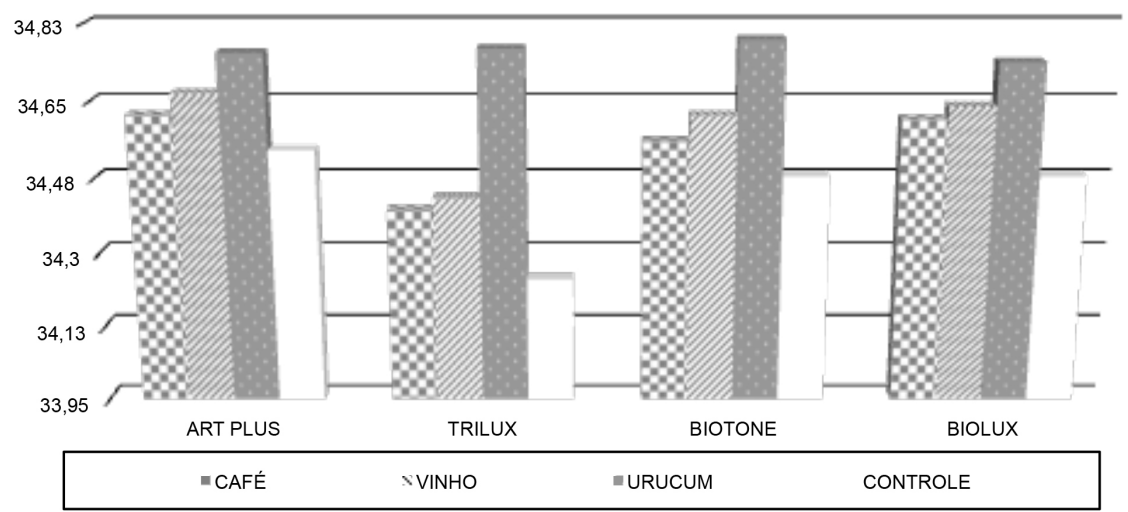

Fig. 1. Specimens after 21 days of immersion.

Table I. Statistical analysis Artplus $x$ Trilux x Biotone $x$ Biolux in the different coloring solutions according to the evaluation periods

\begin{tabular}{ccccc}
\hline & \multicolumn{4}{c}{ (Initial, 7, 14 and 21 days) } \\
Joloring solutions & Artplus & Trilux & Biotone & Biolux \\
\hline wine & $\mathrm{ns}$ & $\mathrm{P}<0.05$ & $\mathrm{~ns}$ & $\mathrm{~ns}$ \\
Cofee & $\mathrm{ns}$ & $\mathrm{P}<0.05$ & $\mathrm{~ns}$ & $\mathrm{~ns}$ \\
Urucum & $\mathrm{ns}$ & $\mathrm{ns}$ & $\mathrm{ns}$ & $\mathrm{ns}$ \\
\hline
\end{tabular}

After analyzing the variables separately, it was observed that in this period, 14 days, the teeth - Trilux presented a significant increase of color change in the two dye solutions (coffee and wine) to the other groups (Art Plus, Bionote and Biolux). However, in the annatto dye, artificial teeth (Trilux) continued to be impregnated, but in larger quantities, demonstrating similar behavior, in the subsequent period of 21 days, to the Art Plus, Bionote and Biolux brands. In this sense, the colorimetric alteration is also dependent on the time factor (Douglas, 2000; Prado Júnior \& Porto Neto; Miyazaki et al.; Gupta et al., 2005; Hollis et al.).

Finally, in view of the results found it can be observed that the stock teeth of the brands Art Plus, Bionote and Biolux, pigmented and stabilized the color faster than the Trilux teeth whose pigmentation was gradual and slower.

\section{CONCLUSION}

The analysis and discussion of the results obtained in the present work, within the conditions established in the experiment, allow this conclusion.

a) The composition of the stock teeth, the type of pigment agent and the duration of contact with coloring agents determine the color change.

b) Urucum was the substance that caused the greatest staining $(p<0.05)$, while coffee and wine had no statistical difference.

c) In relation to trademarks, Trilux presented statistical difference compared to other commercial brands $(p<0.05)$, revealing colorimetric alteration only in the 14 day period. studied, as
day interval. 
MARANHÃO, K. M.; REIS, A. C.; ESTEVES, R. A.; GHISLAIN, H. L.; GARCIA, V.; ALENCAR, E. \& KLAUTAU, E. B. Análisis del cambio de color de dientes artificiales tras inmersión en soluciones colorantes. Int. J. Odontostomat., 13(1):19-22, 2019.

RESUMEN: El objetivo de este estudio fue evaluar la alteración de color de cuatro marcas de dientes artificiales (Art Plus, Trilux, Bionote y Biolux), después de inmersión en soluciones colorantes de café, vino tinto y urucum. Se utilizaron 80 dientes artificiales, los cuales fueron estandarizados con $2 \mathrm{~mm}$ de espesor. En seguida, los mismos fueron sometidos al acabado y pulido, y divididos en 4 grupos $(n=5)$, los cuales fueron inmersos en uno de los 3 tipos de colorante, más agua destilada (control). Las muestras permanecieron inmersas diariamente durante 4 horas, luego fueron retiradas, lavadas en agua corriente, secas con papel absorbente e inmersas en agua destilada por las horas subsiguientes en invernadero biológico a $37^{\circ} \mathrm{C}$, por 21 días. La evaluación del cambio de color se realizó en los períodos de $0,7,14$ y 21 días, por medio del colorímetro tristimulo. Los datos fueron sometidos a la prueba ANOVA y Tukey con un $5 \%$ de significancia. Los resultados demostraron que el urucum fue la sustancia que provocó mayor manchado mientras que el café y el vino no presentaron diferencia estadística. En cuanto a las marcas comerciales, el Trilux presentó una diferencia estadística en comparación con las otras marcas comerciales, revelando alteración colorimétrica sólo en el período de 14 días. Se concluyó que la composición de los dientes artificiales, el tipo de agente pigmentante y el tiempo de inmersión determinan el cambio de color.

PALABRAS CLAVE: cambio de color, diente de stock, colorímetro.

\section{REFERENCES}

Câmara de Sá, G. T. Avaliação in Vitro do Manchamento de Restaurações de Resina Composta. Efeito dos Materiais, Substâncias Corantes e Tempo. Dissertação (Mestrado em Dentística). Rio Grande do Norte, Universidade Federal do Rio Grande do Norte, 2001.

Cardoso, S. O.; Carvalho, E. M. O. F. \& Robazza, C. R. C. Avaliaçäo in vitro do escurecimento dental por meio de escala de cor e análise computadorizada. Rev. Bras. Odontol., 60(1):63-6, 2003.

Chiappetta, D. N. \& Reis, W. L. Avaliação in Vitro da Alteração de Cor em Dentes Artificiais Quando Imersos em Soluções Corantes. Trabalho de Conclusão de Curso (Graduação em Odontologia). Belém, Centro Universitário do Pará, 2005.

Domingues, L. A.; Sakamoto, F. F. O.; Toma, M. H. \& Pegoraro, C. N. Selamentos superficiais influenciam no manchamento das resinas? Rev. Assoc. Paul. Cir. Dent., 55(5):321-5, 2001.

Douglas, R. D. Color stability of new-generation indirect resins for prosthodontic application. J. Prosthet. Dent., 83(2):166-70, 2000.

Ertas, E.; Güler, A. U.; Yücel, A. C.; Köprülü, H. \& Güler, E. Color stability of resin composites after immersion in different drinks. Dent. Mater. J., 25(2):371-6, 2006.
Gupta, R.; Parkash, H.; Shah, N. \& Jain, V. A spectrophotometric evaluation of color changes of various tooth colored veneering materials after exposure to commonly consumed beverages. $J$. Indian Prosthodont. Soc., 5(2):72-8, 2005.

Hollis, S.; Eisenbeisz, E. \& Versluis, A. Color stability of denture resins after staining and exposure to cleansing agents. J. Prosthet. Dent., 114(5):709-14, 2015.

Miyazaki, M. T.; Lovadino, J. R.; Lima, F. A. P. \& Martins, L. R. M. Avaliação do manchamento de compósito modificado por poliácidos com diferentes períodos de envelhecimento. Rev. Assoc. Bras. Odontol., 10(2):113-7, 2002.

Montenegro, C. C. G. X. Análise Quantitativa In Vitro do Grau De Manchamento das Resinas Compostas, Quando Imersas em Solução Corante: Efeito de Materiais, Meio de Imersão e Tempo. Dissertação (Mestrado em Dentística). Rio Grande do Norte, Universidade Federal do Rio Grande do Norte, 2001.

Namem, F. M.; Galan Júnior, J.; Gullo, F. G.; Salin, A. B. \& Santos, L. B. Textura superficial e manchamento de alguns materiais restauradores estéticos. Efeito do acabamento. Rev. Bras. Odontol., 59(4):272-6, 2002.

Prado Júnior, R. R. \& Porto Neto, S. T. Estudo comparativo da estabilidade de cor de materiais estéticos. Efeito de materiais e tempo. Rev. Odontol. UNESP, 29(1-2):31-41, 2000.

Türker, S. B.; Koçak, A. \& Aktepe, E. Effect of five staining solutions on the colour stability of two acrylics and three composite resins based provisional restorations. Eur. J. Prosthodont. Restor. Dent., 14(3):121-5, 2006.

Corresponding author:

Kalena Maranhão

Rus dos Tamios, 1497. Apt 1001

Batista Campos

Belém -PA. Cep: 66025-125

BRAZIL

Email: kalenamaranhao@yahoo.com.br

Received: 18-06-2018

Accepted: 17-10-2018 